\title{
Phylogeny of the Genus Synchytrium and the Development of TaqMan PCR Assay for Sensitive Detection of Synchytrium endobioticum in Soil
}

\author{
Donna S. Smith, Hélène Rocheleau, Julie T. Chapados, Cathryn Abbott, Sharon Ribero, \\ Scott A. Redhead, C. André Lévesque, and Solke H. De Boer
}

First and eighth authors: Canadian Food Inspection Agency, Charlottetown Laboratory, Charlottetown, PE, C1A 5T1, Canada; and second, third, fourth, fifth, sixth, and seventh authors: Agriculture and Agri-Food Canada, Central Experimental Farm, Ottawa, ON, K1A 0C6, Canada. Current address of C. Abbott: Fisheries and Oceans Canada, Pacific Biological Station, Nanaimo, BC, V9T 6N7, Canada. Accepted for publication 28 October 2013.

\begin{abstract}
Smith, D. S., Rocheleau, H., Chapados, J. T., Abbott, C., Ribero, S., Redhead, S. A., Lévesque, C. A., and De Boer, S. H. 2014. Phylogeny of the genus Synchytrium and the development of TaqMan PCR assay for sensitive detection of Synchytrium endobioticum in soil. Phytopathology 104:422-432.

Potato wart, caused by the fungal pathogen Synchytrium endobioticum, is a serious disease with the potential to cause significant economic damage. The small subunit (SSU) and internal transcribed spacer (ITS) ribosomal DNA (rDNA) were sequenced for several Synchytrium spp., showing a high rate of variability for both of these markers among the different species and monophyly of the genus within phylum Chytridiomycota. The intergenic nontranscribed spacer (IGS) of rDNA was sequenced for different pathotypes and showed no intraspecific variation within $S$. endobioticum, similar to the other rDNA markers from this study. To facilitate screening for the pathogen in soil, three TaqMan polymerase chain reaction (PCR) assays were developed from SSU, ITS, and IGS rDNA sequences to detect $S$. endobioticum sporangia in the

chloroform-flotation fraction of sieved soil extracts. In the screening portion of the method, a first TaqMan assay targeting the SSU rDNA was developed with positive results that were further confirmed with amplicon melt analysis. A synthetic reaction control cloned into a plasmid was incorporated into the procedure, facilitating the validation of negative results. The presence of the reaction control did not adversely affect the efficiency of the SSU target amplification. A second TaqMan assay targeting the ITS-1 region was developed as a confirmatory test. There was $100 \%$ accordance between the SSU and ITS-1 TaqMan assays. Utilizing these two assays in tandem achieved good specificity for S. endobioticum, generating negative results with the cloned SSU and ITS-1 regions from all 14 other Synchytrium spp. considered. Spike recovery experiments indicated that these assays, targeting the SSU and ITS-1 rDNA regions, developed from a phylogeny dataset of the genus, could reliably detect a single sporangium in the chloroform flotation fraction of a soil extract. Good correlation between microscopic detection of sporangia and PCR results in both positive and negative soil samples was dually demonstrated for both the SSU and ITS-1 assays.
\end{abstract}

Synchytrium endobioticum (Schilb.) Percival causes wart disease of potato (Solanum tuberosum L.) and is otherwise known as potato wart. Symptoms of the disease on tubers are characterized by a proliferation of infected tissue in tumor-like galls or warts, which render the potato tubers unmarketable. Synchytrium endobioticum is considered a regulated quarantine pest in most parts of the world where potato crops are commercially produced, including Canada, the United States, and the European Union. Because of this, significant economic damage is often incurred as a consequence of disease findings, due to market and long-term production losses resulting from the regulatory quarantine of infested fields and neighboring buffer zones (6).

Potato wart was first described in 1896, in Hungary (40), and was subsequently discovered in most European countries. During the first decades of the twentieth century, wart occurred in Newfoundland, Canada, and several eastern states of the United States, including Pennsylvania, West Virginia, and Maryland (14). In some areas, the disease was widespread. For example, by 1954, the disease had been reported to occur in some 1,130 gardens in 108 towns of Pennsylvania (16). Many infected fields were subsequently chemically treated to eradicate the pathogen but $S$.

Corresponding author: A. Lévesque; E-mail address: andre.levesque@agr.gc.ca

http://dx.doi.org/10.1094/PHYTO-05-13-0144-R

(c) 2014 Her Majesty The Queen in Right of Canada (Canadian Food Inspection Agency). All rights reserved. Use without permission is prohibited. endobioticum was rediscovered in 1987 in Maryland (37). S. endobioticum is currently listed by the United States Department of Agriculture Animal and Plant Health Inspection Service as a "Select Agent" under 7 CFR 331. In Canada, potato wart remains widespread in Newfoundland (14) and was relatively recently found for the first time in Prince Edward Island (11).

$S$. endobioticum is an obligate parasite that does not produce mycelium but produces resting sporangia which germinate into zoospores that infect the epidermal cells of meristematic potato tissue. Summer sporangia, produced in sori, germinate into haploid zoospores which either cause secondary infections directly or conjugate to produce an infectious zygote that ultimately develops into a new resting sporangium. The resting sporangia are very stable and can remain viable in the soil for decades $(6,16)$. The sporangia are spread primarily through infected plant material, infested soil, contaminated equipment, and in the droppings of animals that have fed on infected plant material (30).

There are no approved or registered chemical treatments for potato wart in commercial fields, and the best approach to managing the disease is to prevent its introduction. Potato wart can be eradicated but long-term quarantine of infested fields is required to prevent the spread of the disease while viable sporangia persist. Infested fields need to be monitored for the presence of persistent $S$. endobioticum sporangia in order to manage outbreaks of the disease and prevent introduction of the pathogen into other production areas. For this, a testing program based on a reliable 
and validated method of detection is required. The classic method of detecting $S$. endobioticum sporangia in soil involves sieving soil to enrich for fine particles, separating out an organic fraction, and microscopic examination for visual identification of the sporangia $(15,36)$. This method is time consuming and labor intensive. Replacement or supplementation of the visual detection step with a molecular test method, such as the one proposed herein, is highly desirable in the interest of expediting testing and ensuring accuracy. The fatigue and physical discomfort experienced by analysts after long hours of mental concentration at the microscope, and the associated ergonomic problems which may arise, may contribute to the occurrence of inaccuracies and errors in the analysis. Once potato wart is established in a given growing area and cannot be eradicated, the disease can be managed by identifying the pathotype or the mixture of pathotypes that is present and using resistant varieties $(4,5)$.

The internal transcribed spacer 1 (ITS-1) region of the ribosomal DNA (rDNA) cistron is useful for fungal species identification because of its sequence variability at the species level. In fact, the ITS was recently designated as the optimal DNA barcode for fungi $(2,41)$. Polymerase chain reaction (PCR) methods for the detection of $S$. endobioticum have already been developed for the ITS $(34,45)$ but earlier methods were relatively insensitive, because single sporangia could not be detected in soil. More recently, a more sensitive real-time TaqMan PCR method was developed for the specific detection of $S$. endobioticum in soil targeting the ITS-2 region (46). Assays for S. endobioticum have never been validated for specificity against other Synchytrium spp. and there are no assays with an internal control designed with the same primer pair used for detection. A method was needed that included these two attributes, as well as tests for at least two specific markers to allow confirmation of positive results.
The small subunit (SSU) within rDNA, often referred to as the $18 \mathrm{~S}$ gene, or $18 \mathrm{~S}$, is highly conserved in fungi (41) and has also been selected for microarray-based detection of $S$. endobioticum (1). The SSU has been used extensively for phylogenies, including fungi and members of Chytridiomycota (23), but it was shown that, for this phylum, a multigene approach gives more robust clade support (22). The intergenic nontranscribed spacer (IGS) is at the other end of the spectrum of variability in the rDNA cistron when compared with SSU. Many studies have shown intraspecific variation within this region in fungi (33). Restriction fragment length polymorphisms of the IGS showed intraspecific variation in some chytrids (17).

These previous assays were developed with very little comparative genetic information about other Synchytrium spp. Only three Synchytrium spp. have been included in past phylogenetic analyses (22), while there are over 250 recognized species in the genus, which have been classified under six subgenera (25).

In this article, the phylogenetic relationships and interspecific variation among 15 Synchytrium spp. were determined using rDNA sequences from a collection of related organisms, and variation of the IGS was evaluated for a few pathotypes of $S$. endobioticum. These data were used for the development and validation of a TaqMan PCR method for the sensitive and specific detection of $S$. endobioticum in the organic soil fraction, utilizing the SSU rDNA gene. A confirmatory TaqMan PCR test targeting the ITS1 region is also presented.

\section{MATERIALS AND METHODS}

Specimens and samples for sequencing and detection assays. DNA samples used in this study were obtained from multiple sources. Pure cultures of $S$. endobioticum were not available

TABLE 1. Species, host, and sampling information for fungal strains and specimen that were sequencedin this study

\begin{tabular}{|c|c|c|c|c|c|c|}
\hline Taxon & Strain ID & Sample type & Location $^{\mathrm{a}}$ & Host & Year & GenBank \\
\hline Rhizophydium haynaldii & BR 100 (DAOM-CCFC) & Culture & Quebec & Cladophora glomerata & 1971 & KF160859 ${ }^{b}$ \\
\hline R. patellarium & BR 316 (DAOM-CCFC) & Culture & New Brunswick & Pinus sp. (bait pollen) & 1978 & KF160860 \\
\hline Synchytrium aecidioides & DAOM 170827 & Herbarium & Ohio & Amphicarpa bracteata & 1976 & KF160861 ${ }^{\mathrm{c}}$ \\
\hline S. aecidioides & DAOM 169068 & Herbarium & Ontario & A. bracteata (syn. monoica) & 1978 & KF160862d \\
\hline S. athyrii & DAOM 45778 & Herbarium & British Columbia & Cystopteris fragilis & 1954 & $\mathrm{KF} 160863^{\mathrm{c}}$ \\
\hline S. aureum & DAOM 159823 & Herbarium & Finland & Campanula rotundifolia & 1976 & KF160864 ${ }^{\mathrm{b}}$ \\
\hline S. australe & DAOM 192604 & Herbarium & New South Wales & Modiola caroliniana & 1978 & $\mathrm{KF} 160865^{\mathrm{e}}$ \\
\hline S. collapsum & DAOM (SydowFEE 243) $)^{\mathrm{f}}$ & Herbarium & India & Clerodendron sp. & 1913 & KF160866 \\
\hline S. cupulatum & DAOM 159831 & Herbarium & Finland & Dryas octopetala & 1976 & KF160867g \\
\hline S. decipiens & DAOM 87618 & Herbarium & Wisconsin & A. bracteata & 1961 & KF160868 ${ }^{d}$ \\
\hline S. endobioticum & DAOM (HMR number 1398$)^{\mathrm{h}}$ & Herbarium & Romania & Solanum tuberosum & 1944 & KF160869g \\
\hline S. endobioticum & DAOM 185328 & Herbarium & England & S. tuberosum & 1903 & KF160870g \\
\hline S. endobioticum & DAOM 229326 & Infected potato & Prince Edward Island & S. tuberosum & 2000 & $\mathrm{KF} 160871^{\mathrm{i}}$ \\
\hline \multirow[t]{2}{*}{ S. endobioticum } & DAOM (Dearness & & & & & \\
\hline & species number 3250 ) & Herbarium & Newfoundland & S. tuberosum & 1909 & KF160872g \\
\hline S. epilobii & DAOM $83668^{\mathrm{j}}$ & Herbarium & Wyoming & Epilobium lactiflorum & 1957 & KF160873g \\
\hline S. fulgens & DAOM 24377 & Herbarium & Louisiana & Oenothera laciniata & 1945 & $\mathrm{KF} 160874^{\mathrm{d}}$ \\
\hline S. papillatum & DAOM 192609 & Herbarium & New South Wales & Erodium crinitum & 1983 & KF160875g \\
\hline S. perforatum & DAOM 214019 & Herbarium & Yukon & Valeriana sitchensis & 1960 & KF160876 ${ }^{\mathrm{b}}$ \\
\hline \multirow[t]{2}{*}{ S. plantagineum } & DAOM & & & & & \\
\hline & $(\text { NA Fungi number 2430) })^{\mathrm{k}}$ & Herbarium & Mississippi & Plantago lanceolata & 1888 & KF160877e \\
\hline S. stachydis & DAOM 191879 & Herbarium & Louisiana & Stachys crenata (syn. agraria) & 1963 & KF160878g \\
\hline S. taraxaci & DAOM 132416 & Herbarium & British Columbia & Taraxacum officinale & 1947 & KF160879 \\
\hline
\end{tabular}

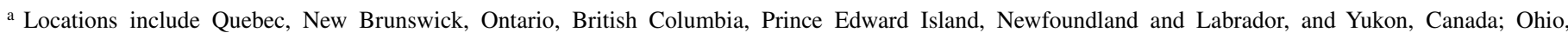

Wisconsin, Wyoming, Louisiana, and Mississippi, United States; and New South Wales, Australia.

b Partial small subunit (SSU) ( $\approx 1,200 \mathrm{bp}$ ), complete internal transcribed spacer (ITS)-1/5.8S, and partial ITS-2.

c Partial SSU ( $\approx 1,200$ bp).

d Partial SSU $(\approx 1,200 \mathrm{bp})$ and partial ITS-1.

e Partial SSU ( $\approx 260 \mathrm{bp})$, complete ITS-1, and partial 5.8S.

f Dearness' set of Sydow, Fungi Exotici Exs. number 243.

g Partial SSU ( $\approx 1,200$ bp), complete ITS-1/5.8S/ITS-2, and partial large subunit (LSU).

h Exsiccate set: Herbarium Mycologicum Romanicum number 1398.

i Pathotype 6, near complete ribosomal DNA cistron with intergenic nontranscribed spacer (missing internal LSU).

j Mycoflora Saximont. Exs. number 1102.

${ }^{\mathrm{k}}$ Dearness herbarium species number 1154 .

1 Partial SSU ( $\approx 250$ bp), complete ITS-1/5.8S/ITS-2, and partial LSU. 
because it is an obligate pathogen; therefore, DNA was extracted from fresh and herbarium-dried symptomatic potato tubers as well as directly from soil (Table 1). DNA was extracted from 55 DAOM (Agriculture and Agri-Food Canada, Ottawa, Mycology) herbarium specimens that belonged to the genus Synchytrium out of a total of $\approx 250$ specimens, if we include some of the additional collections associated with DAOM (Table 1 , footnotes $\mathrm{f}, \mathrm{h}, \mathrm{j}$, and k). Specimens were selected to cover all 40 species available and on the basis of having enough material for DNA extractions. Specimen collection dates spanned 1872 to 1985 . Only two of the available species could not be processed for extraction. Of the 55 extracts, 18 yielded usable Synchytrium DNA which was further processed. We also extracted DNA from pure cultures of two species of another chytrid genus (Table 1). Total genomic DNA was extracted from symptomatic tubers, archival herbarium specimens of Synchytrium spp., and pure cultures of Rhizophydium spp. using the BIO101 Systems FastDNA Kit (QBiogene, Carlsbad, CA).

The $S$. endobioticum sporangia used as positive controls and in spike-recovery experiments were collected from wart-infected tissue removed from symptomatic potato tubers harvested on Prince Edward Island following a localized occurrence of the disease. Wart-infected potato tissue was treated and maintained as per the Spieckermann method for preparing tuber composts of winter sporangia (3).

Sequencing of SSU and ITS rDNA. PCR amplification of partial Synchytrium SSU and ITS rDNA was done using one universal primer and one specific primer (each) to preclude coamplification of nontarget DNA from plant hosts and other soilborne microbes. Two amplicons (Chy18S-269A/ITS4 and NS3/Syn5.8-R) (Fig. 1), which overlapped by slightly $>250$ bp at the $3^{\prime}$ end of the SSU and the ITS-1, were generated. A chytridspecific forward primer (Chy18S-269A; TCGTGYTGGGGAT WGTC) (note: all primers herein are indicated $5^{\prime}$ to $3^{\prime}$ ) positioned $\approx 250$ bp from the $3^{\prime}$ end of the SSU gene was designed using data primarily from James et al. (23) with GenBank SSU sequences from fungi of other phyla. An $\approx 900 \mathrm{bp}$ fragment covering the $3^{\prime}$ SSU and ITS regions was amplified with this forward-specific primer and the universal reverse primer ITS4 (50) positioned at the $5^{\prime}$ end of the large subunit (LSU) rDNA gene. PCR reactions were $20 \mu \mathrm{l}$ in volume and contained 1-5 ng of total DNA, $200 \mu \mathrm{M}$ dNTPs, 4 pmol of each primer, and $1 \times$ TITANIUM Taq DNA polymerase (Clontech Laboratories Inc., Mountain View, CA) in $1 \times$ amplification buffer. PCR cycles were $3 \mathrm{~min}$ at $95^{\circ} \mathrm{C} ; 40$ cycles of $30 \mathrm{~s}$ at $95^{\circ} \mathrm{C}, 45 \mathrm{~s}$ at $55^{\circ} \mathrm{C}$, and $90 \mathrm{~s}$ at $72^{\circ} \mathrm{C}$; and one final cycle of $8 \mathrm{~min}$ at $72^{\circ} \mathrm{C}$. Presumably due to low template quality of the herbarium extracted DNA, PCR product yield was too low in many samples for direct sequencing. In these cases, $10 \mu \mathrm{l}$ of each PCR product was run on a $1.5 \%$ agarose gel and DNA bands were excised and frozen at $-20^{\circ} \mathrm{C}$. Purified PCR product was recovered from each frozen gel slice by squeezing it with a thumb and forefinger between two pieces of parafilm.
Thawed DNA-containing buffer squeezed from gel slices was pipetted into a sterile microtube and the remaining agarose gel was discarded. DNA recovered from the agarose gel was reamplified in reactions of $10 \mu \mathrm{l}$ containing $1 \mu \mathrm{l}$ of a 1:10 dilution of purified PCR product, $200 \mu \mathrm{M}$ dNTPs, 2 pmol of each primer, $3.5 \mathrm{mM} \mathrm{MgCl}$, and $0.5 \mathrm{U}$ of Expand High Fidelity ${ }^{\mathrm{PLUS}}$ Enzyme Blend (Roche Applied Science, Indianapolis, IN) in $1 \times$ amplification buffer. PCR conditions were as described earlier for this primer pair, except that the annealing temperature was increased to $58^{\circ} \mathrm{C}$ and 35 cycles were performed. PCR primers and internal sequencing primers Chy18S-22-F (GTAGGTGAACCTGCGGT) or ITS5 (50) were used for sequencing.

By comparing the 5.8S sequence data from Synchytrium spp. to other chytrids, a Synchytrium spp.-specific reverse primer, Syn5.8-R (CAAACATTTATCATTCASAGT), was designed. For SSU sequencing of Synchytrium spp., a 1,700-bp fragment of rDNA was amplified using universal forward NS3 primer positioned $\approx 500 \mathrm{bp}$ from the $5^{\prime}$ end of the SSU (50) and Syn5.8S-R. Reaction setup and cycling conditions were identical to those described for initial amplification with Chy18S-269A/ITS4, except that the annealing temperature was $56^{\circ} \mathrm{C}$. Some bands were gel-purified and reamplified before sequencing to improve yield following the same methods used for the Chy18S-269A/ITS4 products, except that the annealing temperature was $56^{\circ} \mathrm{C}$ and 40 cycles were performed. Products were sequenced using PCR primers and internal primers Chy18S-1220-R (CTACGGTTA CCTTGTTACGAC), NS5Syn-F (AACTTAAAGGGATTGACGG AAG), and NS4Syn-R (CTTCCGTCAATCCCTTTAAG), the latter two being $1 \mathrm{bp}$ different from NS5 and NS4 (50), respectively.

A similar-length fragment was amplified from DNA extracted from pure cultures of two Rhizophydium spp. (Table 1) using universal primers NS3 and ITS2 (50). Reactions were $20 \mu \mathrm{l}$ in volume and contained $\approx 10 \mathrm{ng}$ of total DNA, $100 \mu \mathrm{M}$ dNTPs, 1.6 pmol of each primer, and $1 \times$ TITANIUM Taq DNA polymerase in $1 \times$ amplification buffer. PCR cycles were $3 \mathrm{~min}$ at $95^{\circ} \mathrm{C}$; a "touchdown" of $30 \mathrm{~s}$ at $95^{\circ} \mathrm{C}, 45 \mathrm{~s}$ at 65 to $61^{\circ} \mathrm{C}$ (dropping $2^{\circ} \mathrm{C}$ per four cycles), and $2 \mathrm{~min}$ at $72^{\circ} \mathrm{C} ; 30$ cycles of $30 \mathrm{~s}$ at $95^{\circ} \mathrm{C}$, $45 \mathrm{~s}$ at $59^{\circ} \mathrm{C}$, and $2 \mathrm{~min}$ at $72^{\circ} \mathrm{C}$; and one final cycle of $8 \mathrm{~min}$ at $72^{\circ} \mathrm{C}$. Products were sequenced using PCR primers and internal primers Chy18S-1220-R, NS4, and NS5.

PCR products were cleaned prior to sequencing using ExoSAPIT (USB Corporation, Cleveland, $\mathrm{OH}$ ) to remove excess primers and dNTPs. Cleaned PCR product (1 to $2 \mu \mathrm{l}$ ) was sequenced using BigDye v3.1 (Applied Biosystems Inc., Carlsbad, CA) and 1.6 pmol primer in a $10-\mu 1$ reaction volume. Sequencing products were run on an ABI 3130xl Genetic Analyzer. Sequence quality and base-calling accuracy were evaluated by viewing chromatograms using Sequencher (Gene Codes Corporation, Ann Arbor, MI).

Sequencing of IGS rDNA. The IGS separates repeat copies of rDNA transcription units, including the ITS and SSU. To investigate the possibility of pathotype-specific sequence polymor-

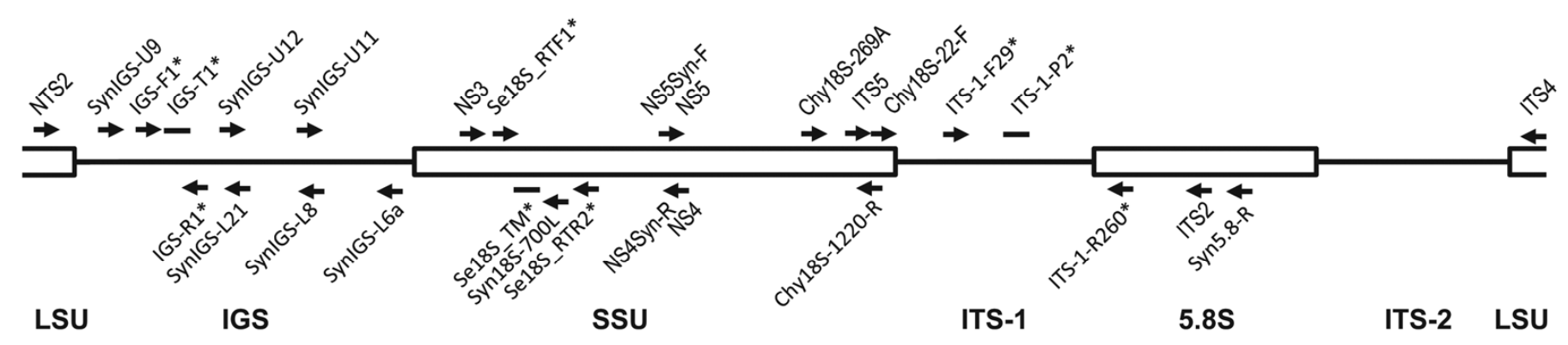

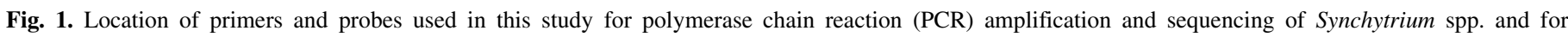

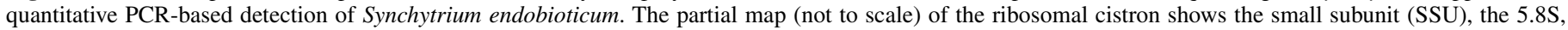

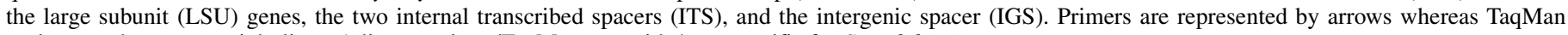
probes are shown as straight lines. Adjacent primer/TaqMan sets with * are specific for S. endobioticum. 
phisms or any intraspecific variation in this quickly evolving region, rDNA sequence data were generated. Specific PCR primers to amplify IGS rDNA for Synchytrium spp. were not available; therefore, an $\approx 4.5$-kb fragment was amplified (from DAOM 229326) (Table 1) using an unpublished universal forward primer in the large rDNA subunit (NTS2; TTTTGATCCTTCG ATGTCGG) and a Synchytrium spp.-specific reverse primer in the SSU (Syn18S-700L; CTTTAAACACTCTAATTTCTTCAC). Reactions were $40 \mu \mathrm{l}$ in volume and contained 1 to $5 \mathrm{ng}$ of total DNA, $200 \mu \mathrm{M}$ dNTPs, $8 \mathrm{pmol}$ of each primer, $2 \mathrm{mM} \mathrm{MgCl}_{2}$, and $2 \mathrm{U}$ of Expand High Fidelity ${ }^{\text {PLUS }}$ Enzyme Blend (Roche Applied Science) in $1 \times$ amplification buffer. PCR cycles were performed as described for the NS3/Synch5.8S primer pair, except that 35 cycles were performed. The PCR product obtained was cloned using the pGEM-T Easy Vector System II (Promega Corporation, Madison, WI) and then sequenced by repeatedly designing internal primers (full list available on request) until the entire fragment had been "walked through."

Sporangia-containing soil samples were obtained for $S$. endobioticum pathotype 1 (The Netherlands, 1990; from collection of M. Hampson, Agriculture and Agri-Food Canada, St. John's, Newfoundland) and pathotype 2 (Avondale, Newfoundland, 2006) (nomenclature following Baayen [4]). Sporangia were obtained from dried wart tissue for pathothype 8 (Avondale, Newfoundland, 1996). DNA was extracted using one of two methods: (i) the UltraClean Soil DNA Isolation Kit (MoBio Laboratories, Carlsbad, CA) or (ii) clusters of spores were hand picked and DNA was extracted using PrepMan Ultra Reagent (Applied Biosystems). To avoid running out of total DNA from pathotype 6 (DAOM 229326) (Table 1) that had been extracted from a fresh tuber, whole-genome amplification was performed on this sample using GenomiPhi v2 DNA Amplification Kit (GE Healthcare, Piscataway, NJ). For this pathotype, whole-genome amplified DNA was used for amplifying IGS fragments. Three overlapping PCR products of IGS were generated for each sampled pathotype using primer pairs SynIGS-U11 (CGTCTTGGACCGAATGAC) and SynIGS-L6a (ATGTTCCCGGTATCGTC), SynIGS-U12 (GGACAAGGAGGGGGAGAC) and SynIGS-L8 (ACACGCA TAATTTGAAGCTC), and SynIGS-U9 (TGTGGCAACGGGAT CACTC) and SynIGS-L21 (TGATATCATGGAGAAAATTAG). Reactions were $10 \mu \mathrm{l}$ in volume and contained 1 to $10 \mathrm{ng}$ of total DNA, $100 \mu \mathrm{M}$ dNTPs, 2 pmol of each primer, and $0.5 \times$ TITANIUM Taq DNA Polymerase in $1 \times$ amplification buffer. Products were sequenced to generate 2,500 bp of contiguous IGS sequence data for each sampled pathotype.

Synchytrium spp. rDNA clones. PCR amplicons generated with the NS3/Synch5.8S primers from S. endobioticum and 14 other Synchytrium spp. were cloned. For S. australe, S. plantagineum, and $S$. taraxaci, only the smaller Chy18S-269A/Syn5.8-R amplicon could be generated; therefore, the clones for these three species contained less than 300 bp of SSU at the $3^{\prime}$ end. Reactions were $40 \mu \mathrm{l}$ in volume and contained 1 to $5 \mathrm{ng}$ of total DNA, $200 \mu \mathrm{M}$ dNTPs, $8 \mathrm{pmol}$ of each primer, $2 \mathrm{mM} \mathrm{MgCl}_{2}$, and $2 \mathrm{U}$ of Expand High Fidelity ${ }^{\text {PLUS }}$ Enzyme Blend in $1 \times$ amplification buffer. PCR cycles were performed as described for the NS3/ Synch5.8S primer pair, except that 35 cycles were performed. The PCR products obtained were cloned using the pGEM-T Easy Vector System II (Promega). Escherichia coli containing the desired plasmid was inoculated into $3 \mathrm{ml}$ of Difco Terrific Broth (BD BioSciences, Mississauga, ON) containing ampicillin at $50 \mu \mathrm{g} / \mathrm{ml}$ and incubated overnight at $37^{\circ} \mathrm{C}$ with circular shaking. Cells were pelleted by centrifugation at $10,000 \times g$ for $2 \mathrm{~min}$ and plasmid DNA was extracted using a mini-prep plasmid purification kit (Qiagen Inc., Valencia, CA). DNA was sequenced for confirmation using the procedure described above with the pGEM SP6 and T7 sequencing primers, and the plasmid DNAs were used to check for false positives in validating the $S$. endobioticumspecific primers.
Phylogenetic and statistical analyses. Alignments were performed with the L-INS-i algorithm of MAFFT (26). For the SSU, the GenBank accessions from James et al. $(22,23)$ were used with sequences obtained from this study and all other rDNA sequences from Synchytrium spp. available in GenBank. Phylogenetic trees were generated using the ATGC PhyML online server (http://www.atgc-montpellier.fr/phyml/), with evolutionary substitution model set to GTR and with 1,000 bootstrap replicates. Trees were viewed and edited using FigTree v1.3.1 (http:// tree.bio.ed.ac.uk/software/figtree/). For analyses of distance matrices, sequences belonging to the genera that were compared with Synchytrium in this study and from Schoch et al. (41), Robideau et al. (39), and Schroeder et al. (42) were aligned and processed with R (38), as described by Schoch et al. (41). The sequences of $S$. decipiens and $S$. aecidioides were removed from this interspecific analysis because they should be considered as a single species (see Discussion).

Selection of primers and probes for PCR detection. The SSU primers and TaqMan probe were manually designed for specific detection of $S$. endobioticum based on sequence alignment with 12 Synchytrium spp. (Table 1). PrimerSelect (Lasergene, version 7.1) was then used to assess primer characteristics during PCR (e.g., dimer formation and so on) whereas freeware from the Integrated DNA Technologies (IDT) website was used to design primers and probes for the ITS and IGS. Primers and probes were purchased from IDT. TaqMan is a registered trademark of Roche Molecular Systems that is licensed exclusively to Applied Biosystems Inc.

Preparation of soil samples for PCR detection assays. Soil samples were collected from various potato fields on Prince Edward Island, some known to be previously infested with potato wart. Soil samples were fractionated according to the method of Hampson and Thompson (15). In all, $\approx 250 \mathrm{~g}$ of dried soil was processed through a sieve tower for $10 \mathrm{~min}$ at a $2-\mathrm{mm}$ amplitude using a sieve shaker (Analysette 3 Spartan, Fritsch, Germany). The sieve tower comprised the following stacked sieves, from top to bottom: number 20 (850- $\mu \mathrm{m}$ mesh), number 60 (250- $\mu \mathrm{m}$ mesh), number 100 (150- $\mu \mathrm{m}$ mesh), number 140 (106- $\mu \mathrm{m}$ mesh), number 200 (75- $\mu \mathrm{m}$ mesh), and number 400 (40- $\mu \mathrm{m}$ mesh).

The sieved fractions, typically $\approx 5 \mathrm{~g}$, were collected in the number 400 sieves. Subsamples of $1 \mathrm{~g}$ were placed in 50-ml polypropylene centrifuge tubes and chloroform $(30 \mathrm{ml})$ was added to the tubes and the contents mixed well. The tubes were centrifuged for $10 \mathrm{~min}$ at $300 \times \mathrm{g}$, and each supernatant was vacuum filtered through a $47-\mathrm{mm}$-diameter, $1.2-\mu \mathrm{m}$ pore size nitrocellulose filter (EMD Millipore Corporation, ABillerica, MA). The filters were dried, and stored in petri dishes at $4^{\circ} \mathrm{C}$. The entire surface of each filter was examined under a dissecting microscope (Carl Zeiss, Oberkochen, Germany) for the presence of sporangia, which were counted when present.

DNA extraction from soil samples for detection. Using filter forceps, the filters were moistened and folded so that the sample material was contained on the inside. The filters were then gently rolled and placed inside $2-\mathrm{ml}$ microtubes, each containing eight 3.2-mm chrome steel beads (BioSpec, Bartlesville, OK). The lysis buffer, consisting of $500 \mu \mathrm{l}$ of Bead Solution (MoBio), was then added, followed by the addition of $200 \mu$ of Inhibitor Removal Solution (MoBio), and $60 \mu \mathrm{l}$ of Solution S1 (MoBio).

The microtubes were then placed in a Mini-Beadbeater 96 (BioSpec) and shaken for $2 \mathrm{~min}$ at 36 oscillations/s. The tubes were centrifuged at $10,000 \times g$ and total DNA was recovered from the supernatant using the Kingfisher milliliter magnetic particle processor (Thermo Scientific Inc., Waltham, MA). Before processing, the wells of the sample tube strip were prepared by adding the following components of the Magnesil Kingfisher Genomic DNA extraction kit (Promega): well 1 had $200 \mu \mathrm{l}$ of magnesil paramagnetic beads and $600 \mu \mathrm{l}$ of lysis buffer KF, well 2 had $1 \mathrm{ml}$ of salt wash, well 3 had $1 \mathrm{ml}$ of alcohol wash, well 4 had 
$1 \mathrm{ml}$ of alcohol wash, and well 5 had $100 \mu \mathrm{l}$ of nuclease-free water. The "PromegaGenomic" program was used to recover the DNA. The eluted DNA in well 5 was transferred to a sterile microtube and stored at $-25^{\circ} \mathrm{C}$ or colder.

TaqMan PCR for detection. Real-time PCR for the SSU, ITS-1, and IGS of S. endobioticum targets was carried out using the RotorGene 3000 (Corbett Life Science, Concord, Australia). Primers and probes for the three targets were used at 0.5 and $0.2 \mu \mathrm{M}$, respectively; sequences are shown in Table 2 . The enzyme mix used was $1 \times$ JumpStart RediMix with SYBR Green $(0.625$ units/reaction) (Sigma Aldrich Corporation, St. Louis, MO), and sterile skim milk powder $(0.2 \% \mathrm{wt} / \mathrm{vol})$ was added to help prevent inhibition (12). Finally, a reaction control plasmid for the SSU (see details below) was included at 50 copies/reaction, and reactions were performed in a total volume of $25 \mu \mathrm{l}$ using $2 \mu \mathrm{l}$ of template DNA. Cycling parameters for the SSU target were as follows: denaturation was $2 \mathrm{~min}$ at $95^{\circ} \mathrm{C}$, amplification was 40 cycles of $15 \mathrm{~s}$ at $95^{\circ} \mathrm{C}$ and $60 \mathrm{~s}$ at $62^{\circ} \mathrm{C}$, and final extension was $3 \mathrm{~min}$ at $72^{\circ} \mathrm{C}$. Cycling parameters for the ITS- 1 and IGS targets were the same, except that an annealing temperature of $68^{\circ} \mathrm{C}$ was used. Fluorescence generated by the TaqMan probe was captured in the Cy5 (for Cy5 or Quasar 670 label) or ROX (for CAL Fluor Red 590 label) channels while SYBR green fluorescence was captured in the FAM channel. For amplicon melt analysis, the temperature was increased from 72 to $95^{\circ} \mathrm{C}$ in $0.5^{\circ} \mathrm{C}$ increments. Fluorescence was acquired in the FAM channel for $5 \mathrm{~s}$ at each increment.

Reaction control for PCR. The reaction control was designed to generate a 184-bp amplicon using primers Se18S_RTF1 and Se18S_RTR2. The sequence (Table 2) was synthesized (IDT), amplified by PCR, and cloned into pCR-TOPOII to generate plasmid pSe18SRC. This plasmid was maintained in E. coli strain DH $\alpha-\mathrm{T} 1$, and was purified, linearized with $B g l \mathrm{II}$, and quantified as previously described for a similar reaction control plasmid (43).

With the reaction control used at 50 copies/reaction, a cycle threshold $(\mathrm{Ct})$ of $\leq 26$ in the FAM channel was required for a valid negative result. Samples generating invalid negative results were cleaned up using reagents and spin columns supplied in the UltraClean Plant DNA Isolation kit (MoBio) and reanalyzed.

\section{RESULTS}

DNA sequencing, phylogeny, and statistical analyses of pairwise distances. We managed to get partial sequences of the rDNA cistron from 15 of the 38 species available in the DAOM herbarium (Table 1). A phylogeny of Synchytrium spp. based on the partial SSU sequences, including all available GenBank accessions of chytrid fungi from James et al. (22,23), was pro- duced and showed $100 \%$ bootstrap support for an internal monophyletic clade comprising all the Synchytrium spp. used in this study (Fig. 2). Herbarium samples of $S$. aecidioides and $S$. decipiens showed a $100 \%$ homology for the SSU region and also showed $100 \%$ homology for the ITS region (data not shown). The isolate of Rhizophydium haynaldii showed 100\% homology with that of GenBank AY635823, identified as R. sphaerotheca and separate from the Rhizophydium clade identified by James et al. $(22,23)$ where $R$. patellarium belonged. It was very difficult to generate a multiple alignment of the ITS region of the Synchytrium spp. because of the very low sequence homology. An analysis of the range of ITS and SSU pairwise distances for several genera of fungi (i.e., true fungi and oomycetes) was used to compare the median and the range of distances within each genus (Fig. 3). We did not find a single base pair difference in rDNA sequences generated from PCR products among strains of $S$. endobioticum (Table 1), including the complete IGS sequences representing four different pathotypes (pathotypes 1,2, 6, and 8) that were generated by cloning. Only IGS data from pathotype 6 was deposited in GenBank (Table 1).

Specificity of primer/probe sets for S. endobioticum. Although specimens of Synchytrium spp. exist in herbaria, there was very little material available to use for DNA extraction, because they are obligate parasites and cannot be cultured. Primers and probes were developed and their specificity was demonstrated using SSU and ITS-1 DNA cloned from several Synchytrium spp. This specificity could not be assessed for IGS because such clones were not available. In all, $\approx 10^{5}$ to $10^{6}$ copies of the SSU/ ITS-1 rDNA region cloned from four isolates of $S$. endobioticum and several different "non-endobioticum" Synchytrium spp. were tested with each primer/probe set. In the TaqMan PCR assay, all four isolates of $S$. endobioticum produced positive results and all the other Synchytrium spp. tested negative (Table 3). This indicated that both the SSU and ITS-1 primer/probe sets were highly specific for $S$. endobioticum.

Effect of reaction control on PCR efficiency. A fivefold dilution series of a preparation containing 100 to 200 sporangia in a pooled mixture of extracts from negative soils was used as template in the SSU TaqMan PCR analysis with 0 and 50 copies/ reaction of the pSe18SRC reaction control. The slopes of the plots of $\mathrm{Ct}$ values versus template dilution generated with 0 and 50 copies of reaction control per $25-\mu \mathrm{l}$ reaction were 3.7 and 3.2, and $r^{2}$ values were 0.996 and 0.982 , respectively (Fig. 4). There was no significant difference detected between the slopes $(P>0.05)$, demonstrating that the addition of 50 copies of pSe18SRC had no effect on the efficiency of the reaction. The pooled slope was 3.4, indicating that the assay had an overall efficiency of $94 \%$.

Sensitivity and limit of detection. A spike-recovery experiment was performed to determine whether the method could

TABLE 2. Primer and probe sequences for Synchytrium endobioticum TaqMan polymerase chain reaction detection

\begin{tabular}{|c|c|c|c|}
\hline Region $^{a}$ & Function & Name & Sequence $^{b}$ \\
\hline \multirow[t]{3}{*}{ SSU(18S) } & Forward primer & Se18S_RTF1 & CTCTGGTTGAGCTCCATTTAC ${ }^{\mathrm{c}}$ \\
\hline & Reverse primer & Se18S_RTR2 & ССТАTTCTATTATTCCATGCTGTA ${ }^{c}$ \\
\hline & TaqMan probe & Se18S_TM1 & TATCCTGGTTCCCCACAGGCACTC ${ }^{\mathrm{d}}$ \\
\hline \multirow[t]{3}{*}{ ITS-1 } & Forward primer & ITS-1-F29 & GGGCGTTCAATTGTTCCAACACCA \\
\hline & Reverse primer & ITS-1-R260 & CGTTGCGAGAGCCAAGAAATCCG \\
\hline & TaqMan probe & ITS-1-P2 & TTTGGTGTATGTGAACGGCTTGCCCACA ${ }^{\mathrm{d}}$ \\
\hline \multirow[t]{3}{*}{ IGS } & Forward primer & IGS-F1 & AAATTCACAAGGCAAGGCTGTGGG \\
\hline & Reverse primer & IGS-R1 & ACTAACCGATTCTTGCAGACCCGT \\
\hline & TaqMan probe & IGS-T1 & ACGGCAGGGTTCCGATGTGAGGCCCTTGAA ${ }^{\mathrm{e}}$ \\
\hline
\end{tabular}

a SSU = small subunit, ITS = internal transcribed spacer, and IGS = intergenic nontranscribed spacer.

b All sequences from 5' to $3^{\prime}$.

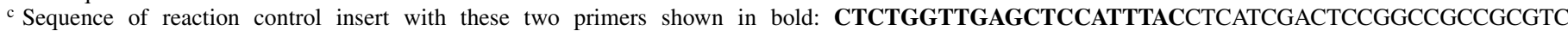
ACGGTCGCCGACTTCGGCGTCGGCCGCATCCTCAACCAGACCATGGACCCCTGCAACTCCTCCGTCGGGACCATCGCCTACATGAGCCCCGAGCGC ATCAGCACCGACCTCAACGTACAGCATGGAATAATAGAATAGG.

'd Modification 5' Cy5 or Quasar 670; 3' Iowa Black RQ or BHQ2.

e Modification 5' CAL Fluor Red 590; 3’ Iowa Black RQ. 
detect as little as a single sporangium of $S$. endobioticum on a filter. Fifteen filters containing negative soil were spiked with single spores. Fifteen positive results were returned for both the SSU and ITS targets, while negative soil samples generated negative results (Fig. 5). Most of the negative samples spiked with a single spore generated $\mathrm{Ct}$ values between 29 and 33 on the Cy5 channel for both the SSU and ITS-1 targets; however, one spiked sample generated relatively late $\mathrm{Ct}$ values of 36.01 and 37.01 for the SSU and ITS-1 genes, respectively (Fig. 5). Some of the negative soil samples generated positive $\mathrm{Ct}$ values with the IGS assay; therefore, because we could not assess cross reactions with other Synchytrium spp. because IGS clones were not available for species other than $S$. endobioticum, this assay was not evaluated further.

Positive results for the SSU target were confirmed by the presence of an $82^{\circ} \mathrm{C}$ melting peak that was easily distinguished from the reaction control peak (Fig. 6A). Positive results for the ITS- 1 target were confirmed by the presence of an $84^{\circ} \mathrm{C}$ melt peak (Fig. 6B).
Comparison between microscopic examination of filters and TaqMan PCR. Filters were prepared from 79 field-soil samples. The filters were examined microscopically, and any $S$. endobioticum sporangia observed were counted and recorded. Total DNA was then extracted from the filters and the extracts were analyzed using real-time TaqMan PCR, targeting the SSU and ITS-1, to compare the efficacy of these PCR methods in validating the known presence of $S$. endobioticum. The results generated using the three methods are summarized in Table 4.

There were 51 filters in which no sporangia were observed. In TaqMan PCR analyses, 48 of these were negative and 3 were positive for both SSU and ITS-1, giving 94\% accordance between the classic microscopic method and the TaqMan PCR method (Table 4) for negative filter samples. In all 51 cases, the positive and negative results of the SSU and ITS-1 analyses were in agreement.

There were 28 sample filters on which varying numbers of sporangia were observed. Of these, 23 samples tested positive for both SSU and ITS-1 in TaqMan PCR. This demonstrated an

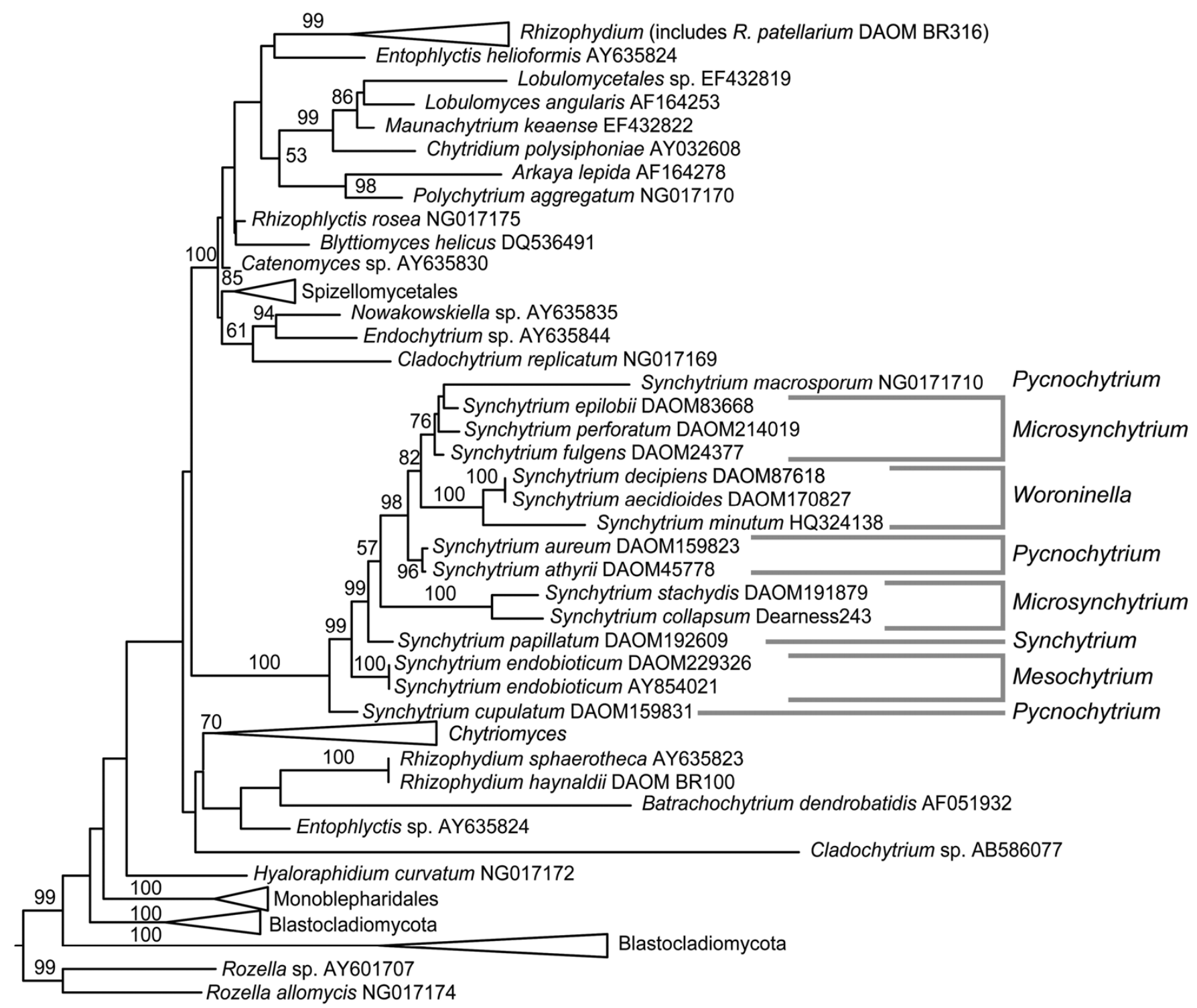

0.2

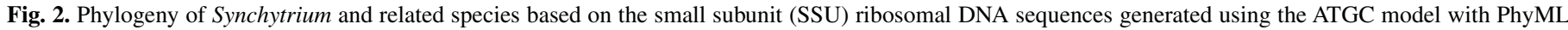

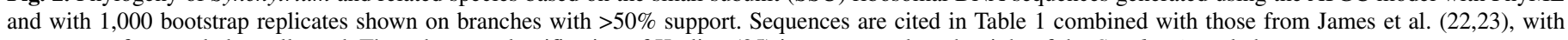
sequences of some clades collapsed. The subgenus classification of Karling (25) is represented on the right of the Synchytrium clade. 
agreement of $82 \%$ between the microscopic examination method and the TaqMan PCR methods. The negative TaqMan PCR results from five positive sample filters suggested that the TaqMan PCR may have an unusually high limit of detection (i.e., poor sensitivity). To determine whether this is a likely explanation for the $18 \%$ discordance in results between the two methods, the data from the filters on which sporangia were observed were categorized according to the number of sporangia observed (Table 5).

If these negative TaqMan PCR results were largely due to a problem with the limit of detection, most of the "false" negative results should have been observed with the filters containing one or perhaps two sporangia. In fact, three of the five PCR negatives were for filters containing three or more sporangia (Table 5). This strongly suggests that the negative TaqMan PCR results were due to another factor other than an inherent lack of sensitivity. It is possible that the sporangia observed on these filters were empty and contained no viable zoospores or detectable DNA, or were misidentified by the microscopic method. Overall, for the 79 soil samples, there was a $90 \%$ agreement rate between the microscopic examination and the TaqMan PCR methods.

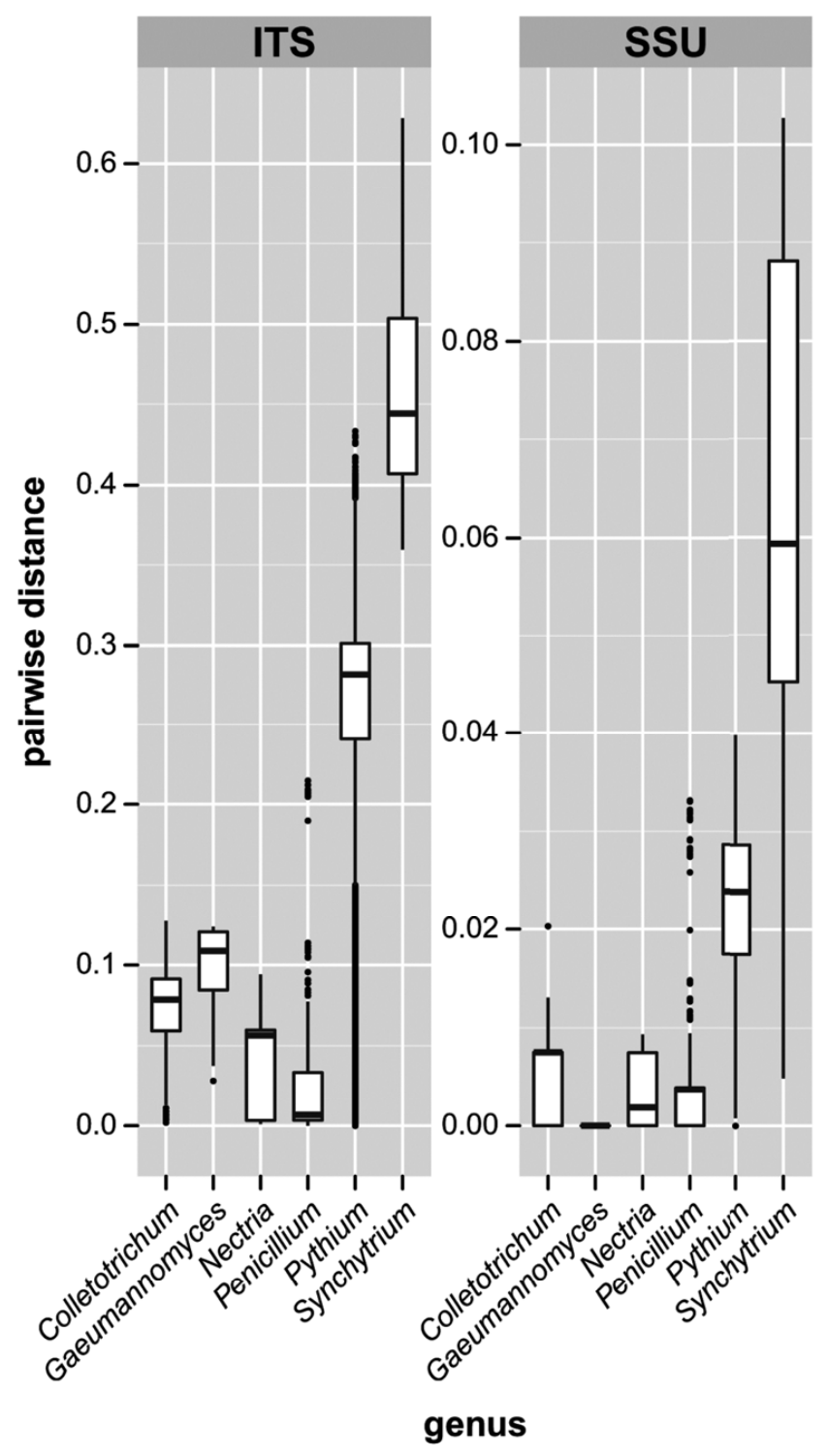

Fig. 3. Pairwise distances within different genera for the small subunit (SSU) and internal transcribed spacer (ITS) region. The line in the middle of the box is the median, the bottom and the top of the box are the 25th and 75th percentiles, and the whiskers are 1.5 times the interquartile range above and below the box limits. Dots are outliers (i.e., beyond \pm 2.7 standard deviations).
Of the 79 samples, 3 failed to generate reaction control FAM Ct values of $<26$, indicating that these reactions were inhibited. These extracts were cleaned up as described above. In repeated analyses, two of these samples were proven to be valid negatives while the third tested positive for $S$. endobioticum using both the SSU and ITS-1 assays (data not shown). This demonstrated the utility of the reaction control for validating negative results.

\section{DISCUSSION}

This study presents the first phylogenetic dataset of the genus Synchytrium and the first detection assay for S. endobioticum validated against a range of Synchytrium spp. The ITS has been commonly used for identification and detection of fungi $(8,9)$ and it was recently compared against other markers for identification

TABLE 3. Specificity of small subunit (SSU) and internal transcribed spacer (ITS) primer/probe sets for Synchytrium endobioticum ${ }^{\mathrm{a}}$

\begin{tabular}{|c|c|c|c|}
\hline \multirow[b]{2}{*}{ Target DNA source } & \multicolumn{3}{|c|}{ Ct value ${ }^{b}$} \\
\hline & SSU & ITS-1 & IRC \\
\hline S. endobioticum 185328 & 14.52 & 15.31 & - \\
\hline S. endobioticum 1398 & 14.59 & 14.62 & - \\
\hline S. endobioticum path. $1^{\mathrm{c}}$ & 13.21 & 14.54 & - \\
\hline S. endobioticum 229326 & 13.86 & 14.54 & - \\
\hline S. aecidioides & Negative & Negative & 23.86 \\
\hline S. athyrii & Negative & Negative & 23.73 \\
\hline S. aureum & Negative & Negative & 23.81 \\
\hline S. australe & N/A & Negative & 23.96 \\
\hline S. collapsum & Negative & Negative & 24.08 \\
\hline S. cupulatum & Negative & Negative & 23.72 \\
\hline S. decipiens & Negative & Negative & 23.54 \\
\hline S. epilobii & Negative & Negative & 23.70 \\
\hline S. fulgens & Negative & Negative & 23.93 \\
\hline S. papillatum & Negative & Negative & 24.08 \\
\hline S. perforatum & Negative & Negative & 23.70 \\
\hline S. plantagineum & N/A & Negative & 23.61 \\
\hline S. stachydis & Negative & Negative & 23.85 \\
\hline S. taraxaci & N/A & Negative & 23.42 \\
\hline pGEM vector & Negative & Negative & 23.45 \\
\hline Potato wart material ${ }^{\mathrm{d}}$ & 20.07 & 21.76 & - \\
\hline
\end{tabular}

${ }^{a}$ Cycle threshold $(\mathrm{Ct})$ values obtained with cloned Synchytrium ribosomal DNA except for the potato sample. Clones were generated from samples listed in Table 1 unless indicated otherwise.

${ }^{b}$ IRC $=$ internal reaction control and N/A = clones with shorter fragments not including the SSU region for the SSU assay.

c Pathotype 1, amplified from soil from the Netherlands, sample from 1990.

${ }^{\mathrm{d}}$ DNA extracted from a suspension of sporangia prepared from potato wart tissue.

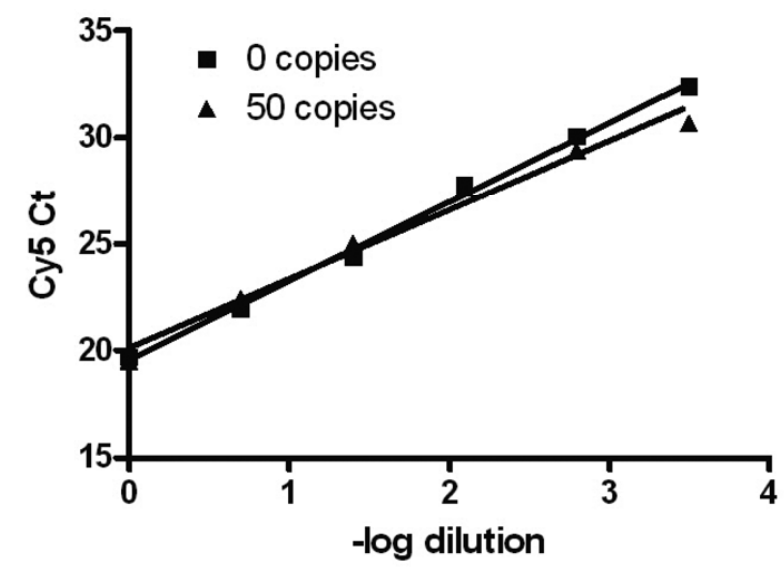

Fig. 4. Effect of reaction control DNA on the amplification efficiency of the Synchytrium endobioticum small subunit target. Cycle threshold $(\mathrm{Ct})$ values generated in the Cy5 channel as a function of target concentration with 0 and 50 copies of the reaction control plasmid in each reaction. 
purposes using a comprehensive panel of strains of true fungi (41) and oomycetes (39). Overall, the ITS out-performed other markers for ease of amplification with universal primers and high interspecific variation compared with intraspecific variation (41). The interspecific variation of the ITS among different genera showed that the genus Synchytrium is more variable than any of the other genera compared (Fig. 3), including the highly variable genus Pythium, which is more likely a complex of different genera (42). Therefore, it was not surprising that the ITS sequence provided the basis for a highly specific detection assay (Table 3). On the other hand, the SSU is well known for its lack of variation at the interspecific level within a genus, and was the poorest marker for species identification of fungi (41). Although our sampling of Synchytrium spp. was partial, it appears that assays based on SSU sequences could easily identify species from this genus (Figs. 1 and 2). S. aecidioides (= S. lagerheimii) has often been mistaken for Uredo aecidioides (syn. S. decipiens) (24), which would explain the $100 \%$ homology for both ITS and SSU between collections labelled $S$. aecidioides and $S$. decipiens as well as between the SSU sequences of $S$. aecidioides from this study and GenBank accession DQ536475. Moreover, the two specimens from this study were found on the same host species (Amphicarpa braceata), which would support their identification as $S$. decipiens, which is known for its very limited host range $(24,25)$. It appears that the genus Synchytrium is a unique case in fungi, where SSU sequences can be used to reliably identify species and, therefore, it is congruent that it provided specificity in the detection assay, even differentiating $S$. papillatum and $S$. cupulatum from $S$. endobioticum, despite being closely related. In

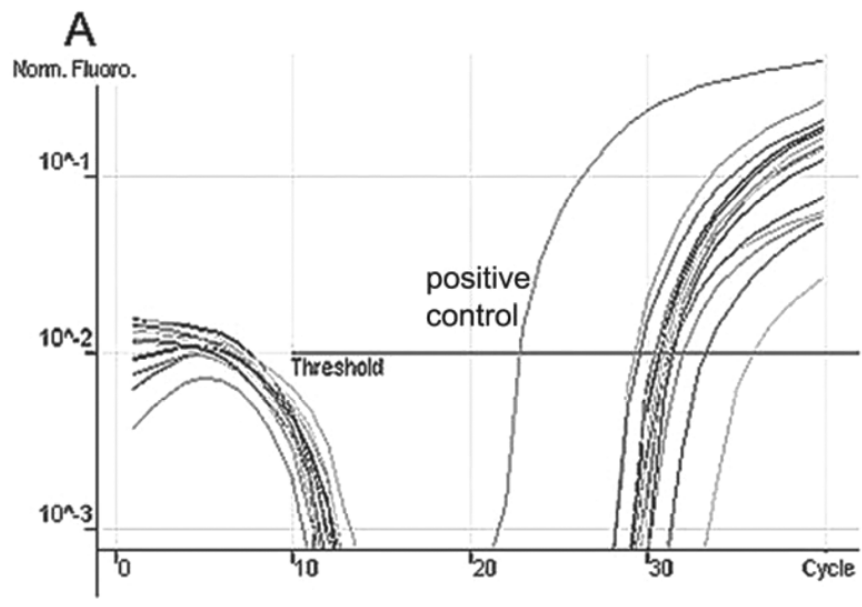

B

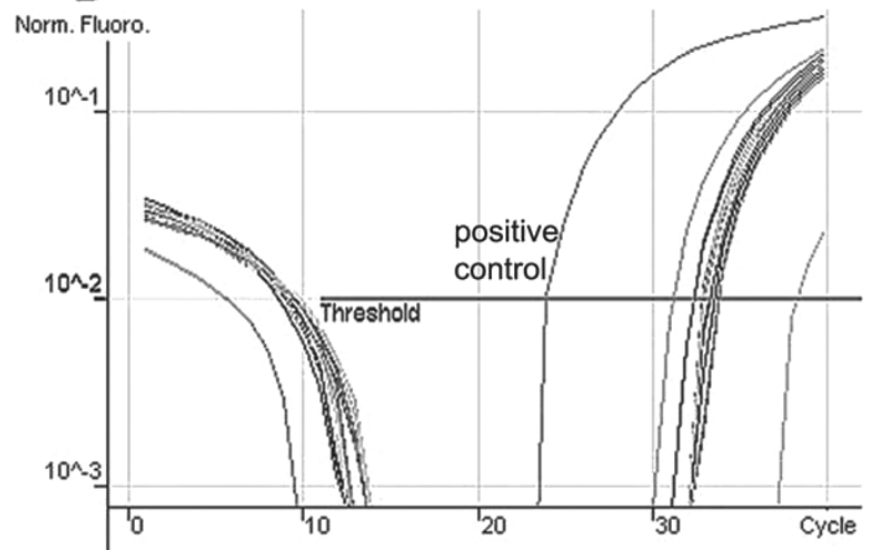

Fig. 5. Cy5 amplification curves of the $\mathbf{A}$, small subunit and $\mathbf{B}$, internal transcribed spacer-1 targets of soil samples spiked with single sporangia. A positive control for each is also shown. A negative extraction control and a notemplate control did not generate fluorescence above threshold. nematology, the SSU rDNA region is used extensively for phylogeny and also for identification (18).

The monophyly of a Synchytrium clade within the phylum Chytridiomycota was strongly supported by the SSU (Fig. 2) and 5.8S (data not shown) rDNA phylogenies, confirming results from James et al. (22) with four species. However, because of poor bootstrap support at a taxonomic level higher than genus Synchytrium, our single gene dataset cannot resolve the placement of Synchytrium among the members of Chytridiomycota, and cannot confirm or refute the placement of Synchytrium within the order Chytridiales, a placement which has been questioned a long time ago $(7,29)$ and an order which was found to be highly polyphyletic (22). A multigene approach would be needed to ascertain phylogenetic relationships at the ordinal level (21). However, within the genus Synchytrium, there are many clades with very strong support, many of which correlate with the subgenus classification of Karling (25). There are $\approx 250$ named species associated with the generic name Synchytrium and, although our sampling was limited, it represented five of the six subgenera, missing only Exosynchytrium, which has only one species (25). Subgenera Pycnochytrium and Microsynchytrium were each represented by four species and are clearly poly-


Fig. 6. Melt analysis of Synchytrium endobioticum A, small subunit (SSU) target with reaction control and $\mathbf{B}$, internal transcribed spacer (ITS)-1 target amplicons generated with negative soil samples each spiked with a single sporangium. Two samples failing to generate SSU and ITS-1 target peaks in both $\mathrm{A}$ and $\mathrm{B}$, respectively, are the negative extraction control and no-template control (circled). 
phyletic, whereas the two species of Woroninella formed a unique clade. Our sampling included the only species of the subgenus Synchytrium (formerly misnamed subgenus Eusynchytrium) and one of the two species in subgenus Mesochytrium, limiting our capability to assess whether the other species in subgenus Mesochytrium, S. desmodii, which is not represented in DAOM, is closely related to $S$. endobioticum or not. Karling (25) had not been able to obtain specimens of this species, either, for his monograph. S. desmodii was reported from Ceylon (= Sri Lanka) as causing wart on apex, leaf, petiole, or stems of Desmodium ovalifolium, a tropical legume used as cover crop in rubber plantations (25) and on seed of this same host from Colombia $(28,31)$. The likelihood of ever having $S$. endobioticum and $S$. desmodii in the same fields would be very low because of their temperate and tropical distribution, respectively.

Rhizophydium is a polyphyletic complex (32). The perfect homology for SSU between $R$. haynaldii (strain BR 100) from this study and $R$. sphaerotheca from GenBank (strain JEL 299) is in agreement with Letcher et al. (32), who found a very high homology between the same strains for the more variable LSU and 5.8S. Our strain BR316 grouped with the Rhizophydium clade from James et al. (22) and was most closely related to Kappamyces sp. within this clade, consistent with the renaming of this strain to Kappamyces sp. by Letcher et al. (32).

The depth of the branches within Synchytrium (Fig. 2) and the high level of interspecific variation within the genus (Fig. 3) indicates a high substitution rDNA rate in this genus. This is consistent with the accelerated evolution and radiation observed in animal- and plant-parasitic nematodes (19). In the Basidiomycete Armillaria, it is believed that plant parasitism, combined with long-range dispersal, has contributed to the radiation of this genus (10). Some Synchytrium spp. are also well adapted for wind dispersal (13). It has been suggested that Synchytrium is a "highly evolved" genus because it is exclusively composed of obligate pathogens that parasitize higher plants, usually with a high level of specificity (7), including race or cultivar host-pathogen interactions in the case of $S$. endobioticum (14).

The rDNA cistron in eukaryotes is present in multiple copies, increasing the sensitivity of molecular assays developed with markers such as the SSU and ITS. Heterogeneity among the different ITS copies within a single strain has been reported in fungi (35) but the absence of differences among sequences obtained using PCR products for sequencing, and those sequences obtained from IGS clones, would support a high homogeneity within Synchytrium spp. In total, 10 single nucleotide polymorphisms (SNPs) over 1,580 bases were observed among the four sequences of the SSU/ITS clones (Table 3) whereas direct sequencing of PCR templates did not reveal any SNPs. This discrepancy is most likely due to polymerization error in the cloned products because the enzyme used for preparing these clones gives high yields but has no error proofing. A high-fidelity enzyme was used to clone IGS products, where $100 \%$ homology was found along the entire cistron. Pathotyping is the only way to identify strain differences in S. endobioticum and we did not see any variation in the IGS among the four pathotypes we compared.
TaqMan assays were developed for specifically detecting $S$. endobioticum based on the SSU and ITS sequences identified in this study. To ensure utility of the molecular assays for detection of $S$. endobioticum for regulatory purposes, we utilized soil from known infected fields as the source of test samples. Extracting DNA from filters containing the chloroform-flotation fraction of sieved soil rather than directly from the sieved soil was more time consuming but it presented two distinct advantages. First, it enabled a direct comparison between the number of spores observed on the filter and the results obtained with the TaqMan method without subsampling. This avoided the complications in data analysis arising from sampling error, which can be significant when the target concentration (i.e., sporangia density in the soil) is low.

An additional advantage was the reduction in the amount of soil present in the sample. Soil can be a difficult matrix for molecular analyses, because it commonly contains substances that co-extract with DNA and strongly inhibit PCR $(44,49)$. With respect to extracting DNA from wet-sieved soil slurries, van den Boogert et al. (45) reported that amplifiable $S$. endobioticum DNA could be recovered from samples spiked with single sporangia in only two of five replicate experiments. Subsequently, a zonal centrifugation method for the separation of single $S$. endobioticum sporangia from soil was developed that demonstrated better recovery of sporangia than wet sieving (48). However, a threshold of at least 10 sporangia was required for detection using PCR (45). Recently, a TaqMan assay from the ITS-2 region was used successfully to detect single sporangia spiked into the supernatant zonal fractions of separated soil (46). Similar results were achieved in our study. We designed our assay within the ITS-1 and SSU regions because we had more sequence data and more rDNA clones from these regions for designing and validating the assay, respectively. We compared the two primers and the TaqMan probe designed by van Gent-Pelzer et al. (46) with all the ITS-2 sequences of Synchytrium spp. we generated, and there was no detectable homology for any of these oligonucleotides. Therefore, it is very unlikely that the assay designed by Gent-Pelzer et al. (46) within the ITS-2 region would cross react with these Synchytrium spp.

TABLE 5. Polymerase chain reaction (PCR) results generated for soil extraction filter samples categorized by the number of Synchytrium endobioticum sporangia counted on each filter as determined by microscopic observation

\begin{tabular}{lccc}
\hline & & \multicolumn{2}{c}{ TaqMan PCR result $^{\mathrm{c}}$} \\
\cline { 3 - 4 } Sporangia $^{\mathrm{a}}$ & Filters $^{\mathrm{b}}$ & Positive & Negative \\
\hline 1 & 4 & 3 & 1 \\
2 & 3 & 2 & 1 \\
3 & 1 & 0 & 1 \\
4 & 1 & 1 & 0 \\
5 & 5 & 5 & 0 \\
$\geq 6$ & 14 & 12 & 2 \\
\hline
\end{tabular}

a Number of sporangia observed.

b Number of filters.

c TaqMan PCR result (small subunit and internal transcribed spacer-1); numbers of positives and negatives.

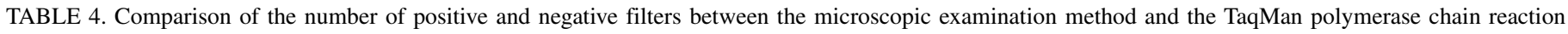
(PCR) method for detection of Synchytrium endobioticum in the chloroform flotation fraction of sieved soil ${ }^{\mathrm{a}}$

\begin{tabular}{|c|c|c|c|c|c|c|c|}
\hline \multirow[b]{3}{*}{$\mathrm{ME}$} & \multirow{3}{*}{$\begin{array}{l}\text { Number } \\
\text { of filters }\end{array}$} & \multicolumn{4}{|c|}{ TaqMan PCR } & & \\
\hline & & \multicolumn{2}{|c|}{ SSU } & \multicolumn{2}{|c|}{ ITS-1 } & \multicolumn{2}{|c|}{ Agreement rate $(\%)$} \\
\hline & & Positive & Negative & Positive & Negative & ME vs TaqMan & SSU vs. ITS \\
\hline Positive & 28 & 23 & 5 & 23 & 5 & 84 & 100 \\
\hline Negative & 51 & 3 & 48 & 3 & 48 & 92 & 100 \\
\hline Total & 79 & 26 & 53 & 26 & 53 & $\ldots$ & $\ldots$ \\
\hline
\end{tabular}

${ }^{\mathrm{a}} \mathrm{ME}=$ microscopic examination, $\mathrm{SSU}=$ small subunit, and ITS = internal transcribed spacer. 
Extraction of DNA from filters was reasonably simple, and both the SSU and ITS1 targets were detected in all of the 15 negative samples that were spiked with single sporangia. The TaqMan assay for the SSU target, diluted into pooled extracts, had an estimated efficiency of $94 \%$, indicating that the matrix typically only had a small influence on the reaction.

Our method had some additional advantages over the previously published TaqMan PCR method of van Gent-Pelzer et al. (46). For example, the internal reaction control presented here utilized the same primers as the SSU target. This ensured that factors influencing the kinetics of the diagnostic reaction would also affect the control reaction in a similar manner (20). Moreover, the control amplicon was larger than the SSU amplicon, providing a reliable validation of negative results. The melt analysis of amplicons from samples in which positive results were first indicated by probe fluorescence in the Cy5 channel consistently confirmed the presence of both the SSU and ITS1 amplicons (Fig. 6). Finally, the inclusion of two targets (ITS and SSU) in the PCR assay, which were co-confirmatory, greatly reduced the likelihood of a false-positive result. As discussed by Vincelli and Tisserat (47), minimizing false-positive results for this organism is critical for surveillance programs, because a positive result would trigger regulatory action and result in economic losses for the grower and the industry.

With field samples, there was a $90 \%$ agreement rate between the TaqMan assays and the microscopic examination method. Because the SSU and ITS1 assays were in $100 \%$ concordance, it is likely that the $10 \%$ of discordant results as per the apparent false-positive PCR results were due to broken sporangia not identifiable by microscopic analysis, or microscopist error (failure to locate sporangia). The most likely causes of the apparent falsenegative PCR results were misidentification of structures resembling $S$. endobioticum sporangia and the microscopic identification of $S$. endobioticum on the basis of empty sporangia. Although confusion of other Synchytrium spp. sporangia with $S$. endobioticum sporangia has been recognized as a lowpossibility source of error in microscopic analysis (3), the latter scenario, involving empty sporangia or nonviable sporangia with completely degraded DNA, is more likely. It is difficult to determine whether a sporangium is viable using only a dissecting microscope at low magnification.

The soil samples used in this study were taken from infested areas where a potato wart outbreak had occurred almost a decade earlier. These areas were under quarantine, and potato had not been cultivated in these fields since the initial outbreak. Therefore, it was not possible to source fresh infections. Hartman (16) demonstrated that the infectivity of wart-infested soil declines after 10 years. Moreover, Laidlaw and Schlenzig (27) observed that populations of viable resting sporangia in soil tend to fall rapidly within the first few years following an infestation, and that most of the nonviable sporangia found in their samples were empty. Therefore, it is likely that some of the soil samples used in this study also contained empty sporangia. One would expect, however, that this would be far less prevalent in soil samples from locations where potato crops are being or have recently been cultivated.

Nonviable spores may contain DNA and generate a positive result with the TaqMan assay. From a regulatory perspective, this would have no new impact. When new outbreaks or positive fields are identified, viable and nonviable spores are not presently differentiated, because the presence of any $S$. endobioticum sporangia in potato field soil is evidence of an infestation and triggers regulatory action

The molecular method for S. endobioticum detection based on the phylogenetic dataset presented in this study has several advantages over the traditional method of microscopic examination in routine diagnostic testing. First, the molecular method is less time consuming, because one analyst can process numerous samples simultaneously. Second, the test was highly specific and objective, eliminating misidentification errors. The implementation of an internal reaction control provided validation for negative results, while the use of two independent molecular targets and the visualization of their respective amplicon melting peaks provided confirmation of positive results. Finally, because the molecular method would not detect empty sporangia, it may be more useful than microscopic examination for determining whether infectious $S$. endobioticum has been eradicated from a previously infested, quarantined field.

\section{ACKNOWLEDGMENTS}

This work was funded partly by the Canadian Safety and Security Program (project number CRTI 04-0045RD). The contributions of Carolyn Babcock, curator of the Canadian Collection of Fungal Cultures, are acknowledged. We thank U. Singh of the Canadian Food Inspection Agency (CFIA) for providing soil samples and potato wart sporangia; and E. Miller and D. Preston, also of the CFIA, as well as H. Kandalaft, R. Assabgui, N. Désaulniers, and T. Rintoul at AAFC for technical assistance.

\section{LITERATURE CITED}

1. Abdullahi, I., Koerbler, M., Stachewicz, H., and Winter, S. 2005. The $18 \mathrm{~S}$ rDNA sequence of Synchytrium endobioticum and its utility in microarrays for the simultaneous detection of fungal and viral pathogens of potato. Appl. Microbiol. Biotechnol. 68:368-375.

2. Anderson, I. C., and Cairney, J. W. G. 2004. Diversity and ecology of soil fungal communities: increased understanding through the application of molecular techniques. Environ. Microbiol. 6:769-779.

3. Anonymous. 2004. Synchytrium endobioticum. EPPO Bull. 34:213-218.

4. Baayen, R., Cochius, G., Hendriks, H., Meffert, J., Bakker, J., Bekker, M., Boogert, P., Stachewicz, H., and Leeuwen, G. 2006. History of potato wart disease in Europe-a proposal for harmonisation in defining pathotypes. Eur. J. Plant Pathol. 116:21-31.

5. Baayen, R. P., Bonthuis, H., Withagen, J. C. M., Wander, J. G. N., Lamers, J. L., Meffert, J. P., Cochius, G., van-Leeuwen, G. C. M., Hendriks, H., Heerink, B. G. J., van-den-Boogert, P. H. J. F., van-deGriend, P., and Bosch, R. A. 2005. Resistance of potato cultivars to Synchytrium endobioticum in field and laboratory tests, risk of secondary infection, and implications for phytosanitary regulations. EPPO Bull. 35:9-23.

6. Baker, E. H., Bell, D., Bourgoin, T., Brown, L., Bulluck, R., Floyd, J., Goldner, L., Hammerschmidt, R., Hesvick, S., Jess, L., Johnson, S. B., Kirk, W., Lopez, L., Perry, S., Poe, S., Secor, G., Sheldon, J., Smith, K., and Stevenson, W. 2007. Recovery plan for potato wart disease caused by Synchytrium endobioticum (Schilberszky) Percival. Natl. Plant Dis. Recov. Syst. 1-23. http://www.ars.usda.gov/research/docs.htm?docid=14271

7. Barr, D. J. S. 1980. An outline for the reclassification of the Chytridiales, and for a new order, the Spizellomycetales. Can. J. Bot. 58:2380-2394.

8. Bruns, T. D. 2001. ITS reality. Inoculum 52:2-3.

9. Capote, N., Pastrana, A. M., Aguado, A., and Sánchez-Torres, P. 2012. Molecular tools for detection of plant pathogenic fungi and fungicide resistance. Pages 151-202 in: Plant Pathology. C. J. Cumagun, ed. InTech, Croatia.

10. Coetzee, M. P., Bloomer, P., Wingfield, M. J., and Wingfield, B. D. 2011. Paleogene radiation of a plant pathogenic mushroom. PLoS One 6:e28545.

11. De Boer, S. H. 2001. Occurrence of potato wart caused by Synchytrium endobioticum on Prince Edward Island, Canada. Plant Dis. 85:1292.

12. De Boer, S. H., Ward, L. J., Li, X., and Chittaranjan, S. 1995. Attenuation of PCR inhibition in the presence of plant compounds by addition of BLOTTO. Nucleic Acids Res. 23:2567-2568.

13. Drinkall, M. J., and Price, T. V. 1983. Dispersal of Synchytrium psophocarpi in Papua New Guinea. Plant Pathol. 32:229-237.

14. Hampson, M. C. 1993. History, biology, and control of potato wart disease in Canada. Can. J. Plant. Pathol. 15:223-244.

15. Hampson, M. C., and Thompson, P. R. 1977. A quantitative method to examine large numbers of soil samples for Synchytrium endobioticum, the cause of potato wart disease. Plant Soil 46:659-664.

16. Hartman, R. E. 1955. Potato wart eradication program in Pennsylvania. Am. Potato J. 32:317-326.

17. Hausner, G., Inglis, G. D., Yanke, L. J., Kawchuk, L. M., and McAllister, T. A. 2000. Analysis of restriction fragment length polymorphisms in the ribosomal DNA of a selection of anaerobic chytrids. Can. J. Bot. 78: 917-927. 
18. Holterman, M., Karssen, G., Elsen, S. v. d., Megen, H. v., Bakker, J., and Helder, J. 2009. Small subunit rDNA-based phylogeny of the Tylenchida sheds light on relationships among some high-impact plant-parasitic nematodes and the evolution of plant feeding. Phytopathology 99:227235.

19. Holterman, M., van der Wurff, A., van den Elsen, S., van Megen, H., Bongers, T., Holovachov, O., Bakker, J., and Helder, J. 2006. Phylumwide analysis of SSU rDNA reveals deep phylogenetic relationships among nematodes and accelerated evolution toward crown clades. Mol. Biol. Evol. 23:1792-1800.

20. Hoorfar, J., Malorny, B., Abdulmawjood, A., Cook, N., Wagner, M., and Fach, P. 2004. Practical considerations in design of internal amplification controls for diagnostic PCR assays. J. Clin. Microbiol. 42:1863-1868.

21. James, T. Y., Kauff, F., Schoch, C. L., Matheny, P. B., Hofstetter, V., Cox, C. J., Celio, G., Gueidan, C., Fraker, E., Miadlikowska, J., Lumbsch, H. T., Rauhut, A., Reeb, V., Arnold, A. E., Amtoft, A., Stajich, J. E., Hosaka, K., Sung, G. H., Johnson, D., O’Rourke, B., Crockett, M., Binder, M., Curtis, J. M., Slot, J. C., Wang, Z., Wilson, A. W., Schussler, A., Longcore, J. E., O’Donnell, K., Mozley-Standridge, S., Porter, D., Letcher, P. M., Powell, M. J., Taylor, J. W., White, M. M., Griffith, G. W., Davies, D. R., Humber, R. A., Morton, J. B., Sugiyama, J., Rossman, A. Y., Rogers, J. D., Pfister, D. H., Hewitt, D., Hansen, K., Hambleton, S., Shoemaker, R. A., Kohlmeyer, J., Volkmann-Kohlmeyer, B., Spotts, R. A., Serdani, M., Crous, P. W., Hughes, K. W., Matsuura, K., Langer, E., Langer, G., Untereiner, W. A., Lucking, R., Budel, B., Geiser, D. M., Aptroot, A., Diederich, P., Schmitt, I., Schultz, M., Yahr, R., Hibbett, D. S., Lutzoni, F., McLaughlin, D. J., Spatafora, J. W., and Vilgalys, R. 2006. Reconstructing the early evolution of fungi using a six-gene phylogeny. Nature 443:818-822.

22. James, T. Y., Letcher, P. M., Longcore, J. E., Mozley Standridge, S. E., Porter, D., Powell, M. J., Griffith, G. W., and Vilgalys, R. 2006. A molecular phylogeny of the flagellated fungi (Chytridiomycota) and description of a new phylum (Blastocladiomycota). Mycologia 98:860871.

23. James, T. Y., Porter, D., Leander, C. A., Vilgalys, R., and Longcore, J. E. 2000. Molecular phylogenetics of the Chytridiomycota supports the utility of ultrastructural data in chytrid systematics. Can. J. Bot. 78:336-350.

24. Karling, J. S. 1957. Synchytrium decipiens and similar species. Mycologia 49:73-82.

25. Karling, J. S. 1964. Synchytrium. Academic Press, New York.

26. Katoh, K., Kuma, K., Toh, H., and Miyata, T. 2005. MAFFT version 5: improvement in accuracy of multiple sequence alignment. Nucleic Acids Res. 33:511-518.

27. Laidlaw, M., and Schlenzig, A. 2005. Studies on the resting spores of potato wart disease in Scotland. In: EPPO Workshop on Synchytrium endobioticum. European and Mediterranean Plant Protection Organization, Paris, France.

28. Lange, L., Lenne, J. M., and Olson, L. W. 1989. Ultrastructural studies of zoosporangium and resting sporangium of Synchytrium desmodii. J. Phytopathol. 125:361-371.

29. Lange, L., and Olson, L. 1978. The zoospore of Synchytrium endobioticum. Can. J. Bot. 56:1229-1239.

30. Langerfeld, E. 1984. Synchytrium endobioticum (Schilb.) Perc.: zusammenfassende Darstellung des Erregers des Kartoffelkrebses anhand von Literaturberichten, Mitteilungen aus der Biologischen Bundesanstalt fuer Land-und Forstwirtschaft; Heft 219. Parey, Berlin.

31. Lenne, J. M. 1985. Synchytrium desmodii, cause of wart disease of the tropical pasture legume Desmodium ovalifolium in Colombia. Plant Dis. 69:806-808.

32. Letcher, P. M., Powell, M. J., Churchill, P. F., and Chambers, J. G. 2006. Ultrastructural and molecular phylogenetic delineation of a new order, the Rhizophydiales (Chytridiomycota). Mycol. Res. 110:898-915.

33. Mirete, S., Patiño, B., Jurado, M., Vázquez, C., and González-Jaén, M. T. 2013. Structural variation and dynamics of the nuclear ribosomal intergenic spacer region in key members of the Gibberella fujikuroi species complex. Genome 56:205-213.

34. Niepold, F., and Stachewicz, H. 2004. PCR-detection of Synchytrium endobioticum (Schilb.) Perc. J. Plant Dis. Prot. 111:313-321.

35. O’Donnell, K. 1992. Ribosomal DNA internal transcribed spacers are highly divergent in the phytopathogenic ascomycete Fusarium sambucinum (Gibberella pulicaris). Curr. Genet. 22:213-220.

36. Pratt, M. A. 1976. A wet-sieving and flotation technique for the detection of resting sporangia of Synchytrium endobioticum in soil. Ann. Appl. Biol. 82:21-29.

37. Putnam, M. L., and Hampson, M. C. 1989. Rediscovery of Synchytrium endobioticum in Maryland. Am. Potato J. 66:495-501.

38. R Development Core Team. 2011. R: A Language and Environment for Statistical Computing. R Foundation for Statistical Computing, Vienna

39. Robideau, G. P., De Cock, A. W. A. M., Coffey, M. D., Voglmayr, H., Brouwer, H., Bala, K., Chitty, D. W., Désaulniers, N., Eggertson, Q. A., Gachon, C. M. M., Hu, C.-H., Küpper, F. C., Rintoul, T. L., Sarhan, E., Verstappen, E. C. P., Zhang, Y., Bonants, P. J. M., Ristaino, J. B., and Lévesque, C. A. 2011. DNA barcoding of oomycetes with cytochrome c oxidase subunit I and internal transcribed spacer. Mol. Ecol. Resour. 11:1002-1011

40. Schilberszky, K. 1896. Ein neuer Schorfparasit der Kartoffelknollen. Ber. Dtsch. Bot. Ges. 14:36-37.

41. Schoch, C. L., Seifert, K. A., Huhndorf, S., Robert, V., Spouge, J. L., Lévesque, C. A., Chen, W., and Fungal Barcoding Consortium. 2012. Nuclear ribosomal internal transcribed spacer (ITS) region as a universal DNA barcode marker for Fungi. Proc. Natl. Acad. Sci. USA 109:62416246.

42. Schroeder, K. L., Martin, F. N., de Cock, A. W. A. M., Lévesque, C. A. Spies, C. F. J., Okubara, P. A., and Paulitz, T. C. 2013. Molecular detection and quantification of Pythium species: Evolving taxonomy, new tools, and challenges. Plant Dis. 97:4-20.

43. Smith, D. S., De Boer, S. H., and Gourley, J. 2008. An internal reaction control for routine detection of Clavibacter michiganensis subsp. sepedonicus using a real-time TaqMan PCR-based assay. Plant Dis. 92:684-693.

44. Tebbe, C. C., and Vahjen, W. 1993. Interference of humic acids and DNA extracted directly from soil in detection and transformation of recombinant DNA from bacteria and a yeast. Appl. Environ. Microbiol. 59:2657-2665

45. van den Boogert, P., van Gent-Pelzer, M. P. E., Bonants, P. J. M., De Boer, S. H., Wander, J. G. N., Lévesque, C. A., van Leeuwen, G. C. M., and Baayen, R. P. 2005. Development of PCR-based detection methods for the quarantine phytopathogen Synchytrium endobioticum, causal agent of potato wart disease. Eur. J. Plant Pathol. 113:47-57.

46. van Gent-Pelzer, M., Krijger, M., and Bonants, P. 2010. Improved realtime PCR assay for detection of the quarantine potato pathogen, Synchytrium endobioticum, in zonal centrifuge extracts from soil and in plants. Eur. J. Plant Pathol. 126:129-133.

47. Vincelli, P., and Tisserat, N. 2008. Nucleic acid-based pathogen detection in applied plant pathology. Plant Dis. 92:660-669.

48. Wander, J. G. N., Van Den Berg, W., Van Den Boogert, P. H. J. F., Lamers, J. G., Van Leeuwen, G. C. M., Hendrickx, G., and Bonants, P. 2007. A novel technique using the Hendrickx centrifuge for extracting winter sporangia of Synchytrium endobioticum from soil. Eur. J. Plant Pathol. 119:165-174.

49. Watson, R. J., and Blackwell, B. 2000. Purification and characterization of a common soil component which inhibits the polymerase chain reaction. Can. J. Microbiol. 46:633-642.

50. White, T. J., Bruns, T., Lee, S., and Taylor, J. 1990. Amplification and direct sequencing of fungal ribosomal RNA genes for phylogenetics. Pages 315-322 in: PCR Protocols, A Guide to Methods and Applications. M. A. Innis, D. H. Gelfand, J. J. Sninsky, and T. J. White, eds. Academic Press, San Diego, CA 